\title{
GENOTYPE AND RESISTANCE PATTERNS OF ANTI TUBERCULOSIS TREATMENT (ATT) IN Mycobacterium tuberculosis ISOLATES FROM TUBERCULOSIS CASES WHICH NOT TAKEN ATT
}

\author{
M. Silvia Merry ${ }^{1}$, Ning Rintiswati ${ }^{2}$, Yanri Wijayanti $\mathrm{S}^{3}$. \\ 1 Tropical Medicine Study Program, University of Gadjah Mada \\ ${ }^{2}$ Microbiology Division, Faculty of Medicine, University of Gadjah Mada \\ ${ }^{3}$ Internal Medicine Division, General Hospital of Dr. Sardjito \\ Corespondence: silvia.tropmed@gmail.com
}

\begin{abstract}
Background: Tuberculosis (TB) is still a prominent health problem which need to be controlled worldwide. In Indonesia, the incidences of TB cases in 2011 were 450.000 cases with mortality rate 175 person per day. The emergence of mycobacterium's resistance against Anti Tuberculosis Treatment (ATT) gives a double burden to prevent the disease. This resistance against ATT is caused by several things, one of which is the nature of mycobacterium, mutations and genotype strain variation.

Objective: The aim of this study is to get a description of ATT's resistance pattern, genotype of $M$. tuberculosis, and determined the correlation between $M$. tuberculosis' genotypes and the resistance pattern against ATT.

Methods: The research methods were cross-sectional and analytical descriptions. Samples used in this research were clinical isolates, which were taken from patients who hadn't received ATT therapy before. Patients were recruited from BP4 (Balai Pengobatan Penyakit Paru = Health Center for Lung's Diseases) at Minggiran and Kotagede area, for the period of June 2010 - December 2010. Drug susceptibility test for ATT were done for Isoniazid, Rifampicin, Streptomycin, and Ethambutol using LJ's proportion method. Whereas for genotyping, we were using PCR-based Spoligotyping, with Dra and Drb primers. Data processing for genotypes and resistance pattern were in descriptive form, while the analysis of the ATT resistance and genotypes correlation were using chi square.

Results: From 33 samples collected and tested for resistancy, 17 samples $(51,52 \%)$ were sensitive to INH, RIF, STREP, and ETAMB while 16 samples $(48,48 \%)$ were resistant to one or more ATT. We found 1 isolate (3.03\%) was MDR TB. Genotype patterns description are 30\% (10 isolates) were Beijing strain and 70\% (23 isolates) were Non Beijing with a variety of EAI, LAM, U, Harleem, T, Manu, and Miscellanous. The chi square's analysis results are $p=0,034(p<0,05)$, ratio prevalence 2,96 (95 CI $0,26-0,57)$.

Conclusion: The result from drug susceptibility test for ATT are 48,48\%, resistant to one regimen or more ATT, while sensitivity 51,52\%. Beijing strains were predominant strain (30\%). There were significant correlation between the patterns of resistance against ATT and genotype patterns, Beijing strains tend to be resistant by 2,96 times greater than non-Beijing strains.
\end{abstract}

Keywords: resistance patterns, patterns of genotype, $M$. tuberculosis, spoligotyping 


\title{
GENOTIPE DAN RESISTENSI Mycobacterium tuberculosis TERHADAP OBAT ANTITUBERKULOSIS PADA ISOLAT PASIEN YANG BELUM DITERAPI OBAT ANTITUBERKULOSIS
}

\author{
M. Silvia Merry ${ }^{1}$, Ning Rintiswati ${ }^{2}$, Yanri Wijayanti $\mathrm{S}^{3}$. \\ 1Program Studi Ilmu Kedokteran Tropis, Universitas Gadjah Mada \\ 2Bagian Mikrobiologi, Fakultas Kedokteran Universitas Gadjah Mada \\ 3Penyakit Dalam, Rumah Sakit Umum Dr. Sardjito \\ Korespondensi: silvia.tropmed@gmail.com
}

\begin{abstract}
ABSTRAK
Latar Belakang: Tuberkulosis masih merupakan masalah kesehatan yang penting untuk dikendalikan secara global. Di Indonesia insidensi kasus TB tahun 2011 sekitar 809.592 dengan angka kematian tinggi. Munculnya resistensi OAT membuat beban ganda penanggulangan penyakit ini. Resistensi OAT disebabkan beberapa hal salah satunya adalah sifat alami, mutasi, dan variasi galur genotipe.

Tujuan: Penelitian ini bertujuan untuk melihat gambaran pola resistensi OAT, pola genotipe $M$. tuberculosis di wilayah Jogjakarta, dan mengetahui hubungan antara pola resistensi OAT dan pola genotipe $M$. tuberculosis.

Metode Penelitian: Metode penelitian adalah potong lintang dan deskripsi analitis. Sampel adalah isolat klinis yang tidak mendapatkan terapi OAT sebelumnya koleksi Laboratorium Mikrobiologi FK UGM yang didapat dari BP4 Minggiran dan Kotagede periode Juni 2010 - Desember 2010. Uji kepekaan OAT dilakukan terhadap Isoniazid, Rifampicin, dan Streptomisin menggunakan metode proporsional LJ, sedangkan genotyping dengan menggunakan Spoligotyping berbasis PCR dengan primer Dra dan Drb. Pengolahan data pola resistensi dan pola genotipe berupa deskripsi, sedangkan analisis hubungan pola resistensi OAT dengan pola genotipe menggunakan chi square.

Hasil Penelitian: Didapatkan 33 sampel yang dilakukan uji kepekaan kuman dengan hasil 25 isolat $(76 \%)$ sensitif terhadap INH, RIF, STREP, 2 isolat $(6,06 \%)$ resisten terhadap INH, 2 isolat $(6,06 \%)$ resisten terhadap RIF, 1 isolat $(3,03 \%)$ resisten terhadap STREP. Poly resistant terhadap RIF dan STREP sebanyak 1 isolat $(3,03 \%)$. Isolat TB MDR adalah 1 isolat (3,03\%). Pola genotipe menggambarkan 30\% (10 isolat) adalah gelur Beijing dan $70 \%$ (23 isolat) Non Beijing dengan variasi EAI, LAM, U, Harleem, T, Manu, dan Miscellanous. Hasil analisis chi square $\mathrm{p}=0,164$ ( $>0,05)$, OR 3,16 (95 CI 0,42 - 22,49)

Kesimpulan: Resistensi yang didapatkan dalam penelitian adalah resistensi primer sebesar 23,24\% sedangkan sensitivitas OAT 76\%. Galur Beijing adalah galur dominan $(30 \%)$. Tidak didapatkan hubungan yang bermakna antara pola resistensi terhadap OAT dan pola genotipenya, namun galur Beijing cenderung berisiko terhadap resistensi 3,16 kali lebih besar dibanding galur Non Beijing.
\end{abstract}

Kata Kunci: pola resistensi, pola genotipe, $M$. tuberculosis, spoligotyping 


\section{INTRODUCTION}

\begin{tabular}{llr}
\multicolumn{1}{c}{ The } & development & of \\
Mycobacterium & tuberculosis & $(M$ \\
tuberculosis) strains which are
\end{tabular}
resistant to ATT is a global problem in the management of tuberculosis. Experts predict that the longer ATTresistant $M$. tuberculosis will be many more. Currently 79\% of cases of MDR$T B$ is a super strains that were resistant to at least 3 or 4 drug antituberkulosis. ${ }^{1}$

Factors causing the emergence of resistant strains of $M$. tuberculosis can be viewed from several aspects, such as bacteriological, human behavior, and the environment. An inadequate ATT therapy can promote the formation of resistant mutants. Prolonged infections due to late diagnosis will also lead to a wider transmission of drug-resistant strains. The transmission doesn't happen only among the patients in the hospital but also to the hospital staff, dormitories, patients' families, and the people around him. Patients with drugresistant bacteria who received shortterm treatment with monotherapy could also lead to multiple-ATT resistant or it called the amplifier effect. This leads to a selective resistant mutations, caused by the providing of ineffective and monotherapy drugs. ${ }^{2}$ Another important factor that greatly contributes to the occurrence of resistance is the mutation of M. tuberculosis.3,4

This mutation, caused by the evolution of $M$. tuberculosis, has implications for some genotypes which enable them to be more resistant than other genotypes. Beijing genotype was one of those genotypes. Beijing type potentially has a higher level of resistance due to a mutation in the putative-mutator gene. ${ }^{5}$ Mutations in the W-Beijing genotype are happening at codon 315 katG gene, catalaseperoxidase gene, which are associated with resistance to isoniazid. Mutations at codon 315 is the most frequent genetic changes that occur in clinical isolates, but in certain areas there will be additional changes at dinucleotide, such as substitution of $A G C \rightarrow A C A$; $\mathrm{Ser} \rightarrow$ Thr; that occurs uniquely in strain at New York.6,7 In addition of Beijing strain, there are other strains which also influenced the clinical appearance of Tuberculosis. For example, the dominant strain of EAI in Vietnam is more potent to cause a pulmonary TB, compared to other strains, and incidence of extrapulmonary tuberculosis is rarely found with this strain. ${ }^{8}$ While in Pakistan, Acute Respiratory Distress Syndrome (ARDS) are often caused by $M$. tuberculosis strains CAS and U9. Other than the distinctive clinical appearances, those strains also have the potential to be resistant against ATT. Identifying these genotypes was done by looking at IS6110 specific segment of $M$. tuberculosis. Various tests developed for IS6110 examination, e.g. RFLP, VNTR, SNP, and spoligotyping. Currently, spoligotyping is considered to have several advantages over other methos, such as need only a small amount of isolated DNA because it is based on DNA amplification by PCR, and able to use fresh clinical specimens such as sputum or other bodily fluids. In addition, the specificity's rate is higher than RFLP10. Efforts to identify of $M$. tuberculosis genotype in Indonesia and to determine its relation to ATT's resistance have been started. A research by Parvati Ida et al., which was also using spoligotyping method, was comparing the distribution of the genotypes in the West Java and East regions. The results of the study found a predominance of Beijing genotype with 33.0\% in West Java and 14.3\% in the East. The strains which were more prevalent in the East is East AfricanIndian (EAI) and the Latin American and Mediteranean (LAM) with 33.3\% and $20.0 \%$. There is no significant relationship between the genotype with the patient's age, vaccination history, 
medical history, and resistance ATT11. Another research was also conducted by Vivi Lisdawati et al. to see the distribution of $M$. tuberculosis genotypes in 10 provinces, which were Palembang, Bandar Lampung, Serang, Jakarta, Bandung, Surabaya, Banjarmasin, Makassar, Pontianak, and Ambon. It was a preliminary mapping studies. Vivi Lisdawati's study found a different distributions pattern when compared with previous research conducted by Parvati et al.. In Vivi's study, the percentage of Beijing strains in the western Indonesia was at $26.61 \%(31.48 \%$ in Sumatra, Java $28.83 \%$, and $19.98 \%$ in Borneo), $25.93 \%$ in Indonesia's central region, while none of this strain was found in eastern Indonesia. There is no significant relationship between genotype and gender, but there is a significant association between genotype and ethnicity as well as geography. A mapping research like the previous has never been done on Jogjakarta's population. Based on the above problems, this study was aimed to look at resistance patterns and $M$. tuberculosis genotypes distribution pattern in Yogyakarta, by looking at the description from the isolates which were obtained by the Faculty's Laboratory of Microbiology and analyze the relationship between the resistance patterns of the ATT and genotypes. The study was conducted in January to December 2012, in the Faculty of Medicine's Laboratory of Microbiology, to test sensitivity to ATT, and Hasan Sadikin Bandung Hospital for Spoligotyping examination.

\section{METHODS}

The research design was crosssectional and descriptive analytics. In this study, the samples were clinical isolates from BP4 at Minggiran and Kotagede. Inclusion criteria for sample selection were: samples with positive result from the smear examination and no previous data on M. tuberculosis's drug susceptibility test were found. The exclusion criteria for sample selection were: contaminated samples and samples that are not growing at week 8. The minimum sample study was set at 30 .

\section{a. Sensitivity Test Against ATT}

This sensitivity test was using $L J$ proportion method. The ATT were Streptomycin $(2 \mu \mathrm{g} / \mathrm{ml})$, Isoniazid 10.2 $\mu \mathrm{g} / \mathrm{ml})$, Rifampicin (1 $\mu \mathrm{g} / \mathrm{ml})$, and Ethambutol $(6 \mu \mathrm{g} / \mathrm{ml})$. Each drug was mixed into solid egg-based LJ media. As a control for bacteria's growth, samples were also grown into a drugfree solid media. Colony suspension was $1 \mathrm{mg} / \mathrm{ml}$ or equivalent to 108 $\mathrm{CFU} / \mathrm{ml}$ and bacterial concentration of $10^{5} \mathrm{CFU} / \mathrm{ml}$ was inoculated on $\mathrm{LJ}$ medium with antibiotics, $L J P N B$ and $L J$ without antibiotics acted as a control. Then $L J$ tubes placed horizontally so that the entire colony came into contact with the surface of the media. Then the media were incubated in a incubator with $37^{\circ} \mathrm{C}$ temperature for 24 hours. After 24 hours, the media was checked to see if they were dry and uncontaminated, then sealed the tubes with paraffin-cotton cap to prevent contamination and keep the media moist enough. Assessment was not done until day 23. If it still could not be assessed by day 23, the growing period should be extended until day 42 and assessed by then. Observations were made every week until the third week and the results were recorded. Results were considered resistant if > $1 \%$ in comparison from the control tube. ${ }^{9,10}$ Observations were made at weeks I, II, and III. The reading results at the week III is the following this formula:

Number of colonies in treated media $\frac{\text { Number of colonies in control media }}{\text { Numb }} \times 100 \%$

Drug-resistant bacteria were indicated by a growth of more than 1\%, whereas 
sensitive bacteria were indicated if there is no growth or growth of less than or equal to $1 \%$.

\section{b. M. tuberculosis' DNA Extraction by the method of boiling.}

An amount equal of 3 loops was taken from the colonies of $M$. tuberculosis to be suspended in $500 \mu \mathrm{l}$ of free molecular water inside $1.5 \mathrm{ml}$ sterile ependorf. Then the suspension is vortexed to destroy and mixed the colony with the water carrier. Furthermore, the colony was heated in a temperature $960^{\circ} \mathrm{C}$ for 30 minutes and followed by 12,000 RPM centrifuge for 5 minutes. Supernatant was separated with the pellets, and the pellets can be stored and for later resuspension. The separated supernatant was examined by electrophoresis with $1 \%$ agarose to prove the existence of DNA. The formation of a tape on agarose was indicating the presence of DNA.

\section{c. Spoligotyping}

Tests performed according to procedures which was done in previous research. An amount of $50 \mu L$ PCR mix mini kit (Isogen Biosolution, BV) consists of $4 \mathrm{~mL}$ dNTPmix $(2.5 \mathrm{mM}$ dNTP; final concentration of $0.2 \mathrm{mM}$ dNTP), $5 \mu$ l 10x conc. Super Tth buffer; $0,1 \mu l$ super Tth polymerase (5 unit/ $\mu l$ ); 4 l primer DRa: 5'-GCT TTT GGG TCT GAC GAC-3' with biotin label at 5' end (20 pmol); $4 \mu \mathrm{l}$ primer DRb: 5'-CCG AGA GGG GAC GGA AAC-3' (20 pmol); $5 \mu \mathrm{L}$ $D N A$ sample dan enough $M Q$ water. We used $10 \mathrm{~mL}$ milliQ as a negative control and Mtb H37Rv $10 \mathrm{~mL}$ and $10 \mathrm{~mL}$ M.bovis BCG as positive control. PCR $D N A$ reaction was done by 20 rounds with the following settings: at a temperature of $96{ }^{\circ} \mathrm{C}-3$ minutes - 1 minute; at a temperature of $55^{\circ} \mathrm{C}-1$ min, and at $72{ }^{\circ} \mathrm{C}-30$ seconds - 5 minutes (Isogen Biosolution, BV). PCR products can be directly used or stored at $-20^{\circ} \mathrm{C}$ for later use. In a new PCR tube add $150 \mu \mathrm{L}$ buffer 2xSSPE / 0.1\% SDS (Isogen Biosolution, BV), which was heated before and $20 \mathrm{~m} \mu L$ PCR product, denaturation was done using thermocycler for 10 minutes at a temperature of $99.9{ }^{\circ} \mathrm{C}$. Then on the mini-blotter MN45 spoligotyping kit membranes has been placed (IM9702, Isogen Biosolution, BV) labeled 43 DNA, Mtb complex's spacer immediately hibridized DNA PCR results. Hybridization was performed for 1 hour at $60^{\circ} \mathrm{C}$. The detection was using ECL solution (Amersham Bioscience, UK) and then exposed to hyper film (Amersham Bioscience, UK). Interpretation of the pattern of results is made in the form of Word and Excel sheets were then compared with data SpolDB4 manually.

\section{RESULTS}

\section{ATT resistance patterns}

From all the samples which were tested, 17 samples $(51,52 \%)$ were sensitive to 4 regimens ATT and 16 samples $(48,48 \%)$ were resistant to one or more of the tested ATT. Resistance to each ATT can be observed in Table 5 below.

Table 1. M. tuberculosis Drug susceptibility test results for several ATT

\begin{tabular}{lccc}
\hline \multicolumn{1}{c}{ Resistance } & Amount & Total amount & Percentage \\
\hline Mono resistant & 12 & 33 & $36,36 \%$ \\
Poly resistant (non MDR) & 3 & 33 & $9,09 \%$ \\
Multi Drug resistant (MDR) & 1 & 33 & $3,03 \%$ \\
Total & $\mathbf{1 6}$ & $\mathbf{3 3}$ & $\mathbf{4 8 , 4 8 \%}$ \\
\hline
\end{tabular}


We found that 16 samples were ATT resistant, where 12 isolates $(36,36 \%)$ were mono resistant. Those resistant samples could be resistant to one or more ATT. Sensitivity pattern of the bacteria to the ATT can be observed in the following table.

Table 2. Mycobacterium resistancy pattern on several ATT

\begin{tabular}{lccc}
\hline \multicolumn{1}{c}{ Resistance } & Amount & Total amount & Percentage \\
\hline Streptomisin & 1 & 33 & $3,03 \%$ \\
Isoniazid & 2 & 33 & $6,06 \%$ \\
Rifampicin & 2 & 33 & $6,06 \%$ \\
Etambutol & 7 & 33 & $21,21 \%$ \\
STREP-INH & 1 & 33 & $3,03 \%$ \\
INH-ETAM & 1 & 33 & $3,03 \%$ \\
STREP-INH-ETAM & 1 & 33 & $3,03 \%$ \\
INH-RIF-ETAM & 1 & 33 & $3,03 \%$ \\
Total & $\mathbf{1 6}$ & $\mathbf{3 3}$ & $\mathbf{4 8 , 4 8 \%}$ \\
\hline
\end{tabular}

The table above shows that 7 isolates (21,21\%) are resistant to Ethambutol. The percentage to Streptomicin and Isoniazid alone are 6,06\% respectively. One of 33 isolates was found to be resistant to Isoniazid and Rifampicin, which is classified in Multi Drug Resistant (MDR), while the other two is classified into poly - resistant (drugresistant mycobacterium other than MDR-TB). There were no isolates were resistant to three types of ATT which were tested.

\section{Genotyping Pattern}

The visualization showed the typical pattern of filling spoligotyping spacers and we can see a typical pattern, with 30\% of all isolates, while $70 \%$ were non-Beijing strains. Beijing and Beijing Like strains are suspected to cause a lot of ATT resistance in some countries.

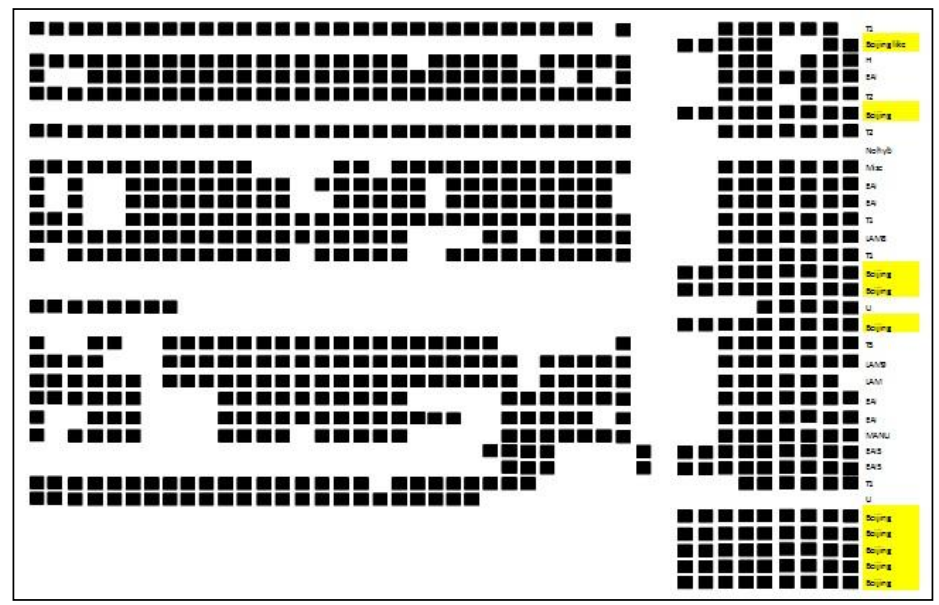

Figure 1. Spoligotyping in M. tuberculosis isolates

spacer 1-33 was not hybridized and spacer 34-43 is filled. A typical pattern of Beijing strain.Beijing genotype patterns appeared to be dominating the result among other genotypes,
A number of 23 isolates were identified as non-Beijing strains with the strain variation of LAM, EAI, T, Harleem, and Miscellanous. The percentages of nonBeijing strains can be seen in the following diagram: 


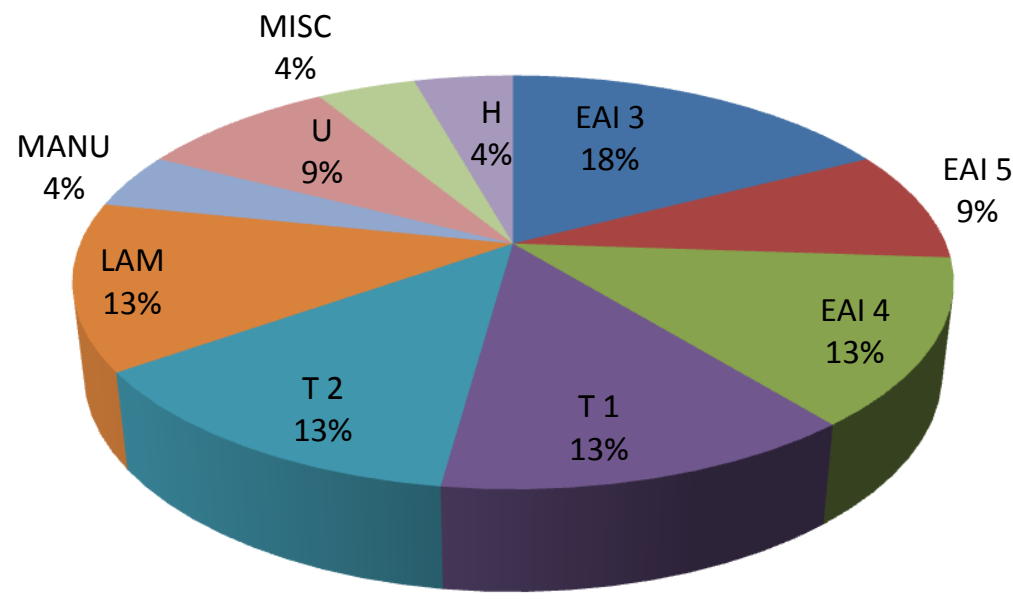

Figure 2. Proportion of Non Beijing's percentage

The diagram above shows the strain variation in Non Beijing strain. Strains were identified as East African-Indian (EAI) varies from EAI2, EAI3, and EAI5 with a percentage between 9-14\%, T1 18\%, Latin American-Mediteranean 14\%, and U 9\%. Manu and T5 was equal to 5\%, while for Harleem (H) and Miscellanous gained 4\%, respectively.

\section{The correlation between M. tuberculosis ATT resistance and genotyping pattern}

Afterward, the genotypes and the resistance patterns were correlated. The correlation showed in Table 3.

Table 3. Correlation of Sensitivity and Genotyping of $M$. tuberculosis

\begin{tabular}{clccc}
\hline No & $\begin{array}{c}\boldsymbol{A} \text { TT } \text { drug susceptibility } \\
\text { test }\end{array}$ & Amount & $\begin{array}{c}\text { Beijing/Beijing } \\
\text { Like }\end{array}$ & $\begin{array}{c}\text { Non } \\
\text { Beijing }\end{array}$ \\
\hline 1 & Resistant to $S$ & 1 & - & 1 \\
2 & Resistant to I & 2 & 1 & 1 \\
3 & Resistant to $R$ & 2 & 2 & - \\
& Resistant to E & 7 & 4 & 3 \\
4 & Resistant to S I & 2 & - & 2 \\
5 & Resistant to I E & 1 & 1 & - \\
6 & Resistant to IRE & 1 & 1 & - \\
\hline
\end{tabular}

The table above shows that Beijing and non-Beijing strains have a tendency to be resistant against or sensitive toward ATT. From the data, Chi square analysis was performed. The results from the analysis shows that there is statistically significant correlation ( $p>0.05$ ) between the variable genotypes with ATT resistance with ratio prevalence 2,96 . It means that the Beijing genotype will be more likely become resistant by 2,96 times greater when compared with nonBeijing genotype. 


\section{DISCUSSION}

\section{ATT Resistance Patterns}

In this study, data from sensitivity test shown $51,52 \%$ sensitive toward ATT, while 48,48\% resistant against ATT. These results differ from Wijayanti and Rintiswati (1998) result which the resistance against ATT rates were $88.10 \%$ for one or more of type of ATT, 3.58\% resistant to all ATT regimen and $11.90 \%$ sensitive toward ATT. ${ }^{11}$ This difference result occured because Wijayanti and Rintiswati's study used samples of clinical isolates from difficult cases, from patients who did not improve clinically in a certain time. Resistance found in that study was secondary resistance. Patterns of primary and secondary resistance are an important consideration for the treatment and monitoring mechanism of patient with TB.

Lestari's (2003) study showed a quite different pattern of resistance as well. Study was conducted in the DIY Province in July-October 2002 period. This study described resistance pattern of $M$. tuberculosis against INH, Rifampicin, Ethambutol, and Streptomycin and also examined the sputum smear conversion at the end of the study. The results of the study found resistance to INH (61.5\%), streptomycin (46.2\%), and Ethambutol (30.8\%), while resistance to Rifampisin was not found. 12 The high rates of resistance in this study were also influenced by other factors which were the nutritional status, contact history, and history of previous medication with INH. Socioeconomic factors were also an influence, because most people with a low education level have low income anyway. In this study, resistance that occurred was not clear whether they were primary or secondary. The interesting thing was no discovery of Rifampicin resistant samples, while our study showed resistance rate to Rifampicin by 25\%. This shows that the developments of TB cases that are resistant to first-line drugs need special attention.

Resistance patterns also differed between regions. Different with the Wijayanti and Rintiswati's study which was located in Jogjakarta, the results of Nurhayati's study (2004) in Central Sulawesi Donggala suggests that as many as $32.8 \%$ of the sample is sensitive to all first-line regimen ATT, while $67.1 \%$ were resistant to one or more types of ATT. The highest resistance found was to rifampicin (11.5\%) while the lowest was on INH (2\%). In the study, researchers examined the high rates of resistance caused by patient compliance and monotherapy before combined ATT. Similar risk factors which were acquired from two studies by Lestari and Nurhayati suggested that the differences in resistance patterns between the two areas, were not caused by socio-economic factors, consumption of drugs, and noncompliance of the patient only, but also other factors, such as the nature of biological bacteria itself. Each strain has its own biological properties which differs them from other strains.

Resistance pattern in some other countries also showed different results. The results in Tianjin China shows that $32 \%$ of new TB patients in with dual resistant, $6 \%$ of them showed multidrug resistant. Meanwhile, in patients who had previously been treated with ATT$T B$ showed dual resistance by 55\% and MDR TB found in 32\% pasien. ${ }^{13}$ The high rates of resistance in the China's population was primarily because of low patient compliance in taking medication and frequent provision of short term therapy by clinician.14,15 Meanwhile, research in India showed the resistance in new TB cases is equal to 1.7 to $2.3 \%$ and in category II TB cases found $20.4 \%$ poly resistant. ${ }^{16}$ 


\section{Genotyping Pattern}

Mapping with spoligotyping showed that 10 samples (30\%) were Beijing strains, and $70 \%$ were nonBeijing strains. A sample that was not hybridized, indicating that that isolate was MOTT. The percentage of Beijing strains is consistent with research Parwati (2008) which revealed approximately 30-35\% of the population of $M$. tuberculosis in Java consists of Beijing strains. The percentage of the population is different from the other islands, like the population of the island of Timor, where M. tuberculosis strains was dominated by EAI with 33.3\%.17 It was also shown in a study conducted by Lisdawati et al.., (2010). Mapping results revealed that the percentage of Beijing strains in Java amounted to 28.83\%.18 The Non-Beijing strains, which were found in this study, was dominated by the EAI and the a variation of the strain LAM, $U, T$, Harleem, Manu, and Miscellanous. Strains are derived from the major clades, consistent with the results of the mapping by Lisdawati et al.., (2010) in ten cities of Indonesia. ${ }^{17}$

Genotype patterns showed variations in some countries, in line with the theory of evolution and distribution of $M$. tuberculosis. Beijing strains dominate East Asia and Central Asia by $10 \%$, and worldwide by $13 \%$, according to the distribution of Chinese ethnicity. Other strains which are predominant in Asia, especially Southeast Asia, is EAI. Harleem original strains are strains which is found in the United States and the Caribbean with the highest percentage in Venezuela (65\%). Currently Harleem strains are found scattered in the coastal areas and islands around the world. It was associated with colonization routes of Colombus. ${ }^{19}$ In the study sample, we found Harleem strain by 4\%, but because we do not explored further on sample characteristics such as origin of ethnicity and the area they lives, distribution pattern cannot be concluded.

Other strains also has its own characteristics. LAM strains were identical to Manu strains which is native to Asia Minor, India, Cameroon and Tanzania. Manu strains identified by the absence of spacers 33-36, vary between sub-division (Manu 1 - Manu 3). Similar strains are located near strain T. In further developments, the spread of this strain along with the expansion and mobilization of the people from those regions. In addition to worldwide distribution, the distribution pattern of these genotypes can be used to see the transmission of bacteria and infection sources. A person infected with the same strain of TB with the people that lives in the same house can be used to describe the transmission source, while the people in the house who have a different strain of the bacteria showed that each member of the family infected by different sources. Genotype data of each members can serves as an overview of the $M$. tuberculosis' molecular epidemiology of and taken into consideration in the control of transmission and therapy. ${ }^{20}$

\section{The correlation between the resistance against ATT pattern and genotyping patterns}

Some strains of $M$. tuberculosis are considered to have a higher tendency to be ATT resistant than the other strains. Beijing and Beijing Like strains are some of the strain that many scientists called as a high risk of ATT resistant, supported by the research that was conducted by Githui et al.. in Kenya, Nairobi (2004) and Mistry et al.. in India (2001). Result from these studies were showing the connection between high-risk strain with the occurrence of ATT resistant. ${ }^{21,22}$ In Indonesia, research on the association between genotype and ATT resistance patterns has been studied by Parvati and Lisdawati, with 
the result of no direct correlation between Beijing strains and ATT resistance. ${ }^{17,18}$ The results Asiimwe's study (2008) in Kampala, Uganda and Glynn et al. (2005) in Northern Malawi also showed no statistically significant association between Beijing strains and ATT resistance. 5, 23

The link between Beijing and Beijing Like strains like with drug resistance has not been definitively revealed by researchers. Several hypotheses attempt to explain this association. The first hypothesis is that there is resistance to the vaccine BCG. ${ }^{6}$ The second hypothesis is that the type of Beijing has a higher level of resistance due to a mutation in the putative mutator gene. ${ }^{5}$ Mutations in the Beijing genotype is happening at codon 315 katG gene, catalase-peroxidase gene, which is associated with resistance to isoniazid. Mutations at codon 315 is the most frequent genetic changes occur in clinical isolates. Next argument about the correlation of this resistance is the single IS1660 insertion in the region of NTF. ${ }^{6}$ Determining a link between Beijing genotype with clinical appearance has been widely studied. For example, there was a study in Vietnam to see the correlation between Beijing genotype with the risk of relapse and treatment failure. The results of this study was that there was a significant association between Beijing genotype with relapse and failure of treatment. ${ }^{24}$ Research done by Hasan showed a significant association between Beijing genotype with MDR TB incidences in Pakistan. ${ }^{25}$ The association between Beijing genotype with disease severity, such as the occurrence of fever, showed a strainspecific pathogenesis. ${ }^{26}$ The diversity of these results opened up opportunities for similar studies in order to give a better understanding of the genotype information which has a significant clinical meaning.

\section{CONCLUSION}

From this study we can conclude that the rate of resistance varies among regions, based on characteristic of the isolates sample. The resistance found in this study was $48,48 \%$ and the sensitivity was $51,52 \%$, with 1 isolates (3.03\%) were MDR TB. Genotype pattern which we found showed the lines of distribution, transmission of bacteria and origin of contagion. Beijing strain genotype patterns were identified by 10 isolates (30\%) and the rest were non-Beijing. There is significant statistical association between Beijing strains and ATT resistance, but there is a tendency for resistance in Beijing strains, 2,96 times more likely than non-Beijing strains.

The sample in this study was not known in demographic characteristics (age, sex, region) so it can't be analyzed about the spreading and transmission. Therefore, a complete data of research need to be done so that it can be used to describe the condition of isolates in Jogjakarta and to do phylogenetic analysis to trace patterns of kinship and molecular epidemiology of $M$. tuberculosis. Continued research on the mutations of ATT resistant strains is also necessary to look at the incidence of mutations in certain strains, and their association with ATT resistance.

\section{REFERENCES}

1. Aditama, TY., Priyanti, Z., . Tuberkulosis Diagnosis, Terapi dan Masalahnya Edisi V. Yayasan Penerbitan Ikatan Dokter Indonesia, Jakarta; 2002

2. Lidjaja, A., Maidin, A., Retnoningrum, DS.,,Badaruddin, F., Genetic Diversity Analysis of Mycobacterium tuberculosisto Isoniazid and Rifampicin Sensitive and Resistance Isolate. J. Sains\&Teknologi, 9(3);2009200 - 5 
3. Gillespie, SH. Evolution of Drug Resistance in Mycobacterium tuberculosis: Clinical and Molecular Perspective;2002 : 46(2): 267-274

4. Retnoningrum, DS.,Kembaren, RF.,. Mekanisme Tingkat Molekul Resistensi terhadap Beberapa Obat pada Mycobacterium tuberculosis, Acta Pharmaceutika Indonesia;2004: 29 (3): 92-95

5. Glynn, JR., Crampin,AC., Traore, H., Yates, MD., Mwaungulu,FD., Ngwira, BN., et al.,. Mycobacterium tuberculosis Beijing Genotype,Northern Malawi, Emerging Infectious Diseases;2005 : 12 (1): 150-154

6. Bifani, P., Moghazeh, S., Shopsin, B., Driscoll, J., Ravikovitch, A., Kreiswirth, RN.,. Molecular Characterization of Mycobacterium tuberculosisH37Rv/Ra Variants: Distinguishing the Mycobacterial Laboratory Strain. $J$. ClinMicrobiol;2002: 38(9) 3200-4

7. Filliol, I., Drescoll, JR., van Soolingen, D., Kreiswirth, BN., Kremer, K., Valetudie, G., et al. Global Distribution of Mycobacterium tuberculosis Spoligotypes.Emerging Infectious Diseases; 2002: 8(11): 1347-49

8. Caws, M., Thwaites, G., Dunstan, S., Hawn, TR., Thi Ngoc Lan, N., Thuong, NT.,et al.. The Influence of Host and Bacterial Genotype on the Development of Disseminated Disease with Mycobacterium tuberculosis, PLoS Pathogens 4(3): e1000034.doi:10.1371/ journal.ppat. $1000034 ; 2008$

9. Salahuddin, N., Tanveer, M., Rao, N., Akram, S., Hasan, Z., Hasan, R.. Mycobacterium tuberculosis Genotypes inpatients developing pulmonary tuberculosis related acuterespiratory distress syndrome, Sri Lanka Journal of Critical Care; 2011: 2(1):20-24
10. Ramazanzadeh, R., Farnia, P., Amirmozafari, N. Characterization of Mycobacterium tuberculosis complex isolated from Iranian and Afghani Patients by Spoligotyping Method. Brazilian Journal of Microbiology; 2009 : 40(3):314-320

11. Parwati, I., von Crevel, R., Sudiro, M., Alisjahbana, B., Pakasi, T., Kremer, K., et al. Mycobacterium tuberculosis Population Structures Differ Significantly on Two Indonesian Islands. J ClinMicrobiol; 2008 : 46(11): 3639-3645

12. Lisdawati, V., Parwati, I., Sudarmono, P., Sudiro, TM.,Ramadhany, R., Puspandari, N. Studi Pemetaan Awal DNA Mycobacterium tuberculosis complex secara Spoligotyping pada hasil isolasi dahak pasien tuberculosis parudari $10 \mathrm{ibu}$ kota propinsi (bagian I). Buletin Penelitian Kesehatan;2010 : 38 (4):169-185

13. McEvoy, REC., Warren, RM., van Helden, PD. Molecular methods and their application in tuberculosis epidemiology, Saunders Elsevier, New York;2009.

14. National Committee for Clinical Laboratory Standards. Susceptibility testing of mycobacteria, nocardia, and other aerobic actinomycetes. Tentative Standard M24-T2, 2nd. ed. NCCLS;2006.

15. Rintiswati, N., Wijayanti, Y. Kepekaan Mycobacterium tuberculosis terhadap obat anti tuberculosis. Berkala Ilmu Kedokteran;1999: 31 (2): 77-83.

16. Lestari, SH. "Pola Resistensi Kuman Mycobacterium tuberculosis terhadap Obat Anti tuberkulosis (OAT) Propinsi Daerah Istimewa Yogyakarta", Program Pascasarjana IKM. Universitas Gadjah Mada. Yogyakarta ;2003. 
17. Nurhayati, "Pola Resistensi Mycobacterium tuberculosis terhadap Oba tAnti tuberculosis di Kabupaten Donggala, Sulawesi Tengah", Program Pascasarjana Ilmu Kedokteran Tropis, Universitas Gadjah Mada, Jogjakarta;2004.

18. Qi, W., Harries, AD., Hinderaker,Performance of culture and drug susceptibility testing inpulmonary tuberculosis patients in northern China, Int J Tuberc Lung Dis, 2011: 15(1):137-139

19. Liang, L., Wu, Q., Gao,L., Hao,Y., Liu,C., Xie,Y. Factors contributing to the high prevalence of multidrugresistant tuberculosis: a study from China, Thorax;2012: 67:632-638

20. Zhao B, Pang Y, Zhou Y, Liu G, Jiang G. Spoligotyping and Drug Resistance Analysis of Mycobacterium tuberculosis Strains from National Survey in China, PLoS ONE 7(3): e32976. سdoi:யس10.1371/journal.pone. 0032976;2012

21. Sharma, R., Gupta, V., Spoligotyping for the Detection ofMycobacterium Complex Bacteria 2011 ; diunduhЦdari http://www.ocimumb.com diakses[tanggal 3 November 2012

22. Brudey, K., Driscoll, JR., Rigouts, L., Prodinger, WM., Gori, A., Al-Hajoj, SA., et al. Mycobacterium tuberculosiscomplex genetic diversity: mining the fourth international spoligotyping database (SpolDB4) for classification, population genetics and epidemiology.

$\mathrm{BMC}$

Microbiology;2006: 23(6):1471-88

23. Mokrousov, I., Ho Minh Ly, Otten, T., Origin and primary dispersal of the Mycobacterium tuberculosis Beijing genotype: Clues from human phylogeography, Genome Res;2005: 15: 1357-1364

24. Gori, A., Bandera, A., Marchaetti, G., Esposti, AD., Catozzi, L., Nardi, GP.,et al., Spoligotyping and Mycobacterium tuberculosis. Emerging Infectious Diseases;2005: 11(8): 1242-8

25. Githui,WA., Jordaan,AM., Juma,ES., Kinyanjui,P., Karimi,FG., Kimwomi,J., Meme,H., Identification of MDR-TB Beijing/W and other Mycobacterium tuberculosis genotypes in Nairobi, Kenya, Int J Tuberc Lung Dis;2004: 8(3):352-360

26. Mistry,NF., Iyer,AM., D'souza, D., Taylor, GM., Young,DB., Antia, NH., Spoligotyping of Mycobacterium tuberculosis Isolates from MultipleDrug-Resistant Tuberculosis Patients from Bombay, India, J ClinMicrobiol;2002: 40(7): 2677-2680

27. Asiimwe, B., Ghebremichael, S., Kallenius, G., Koivula, T., Joloba, M., Mycobacterium tuberculosis spoligotypes and drug susceptibility pattern of isolates from tuberculosis patients in peri-urbam Kampala, Uganda, BMC Infectious Diseases; 2008: 8:101 doi:10.1186/1471-2334-8101

28. Thi Ngoc Lan, N., Thi Kim Lien, H., Tung, LB., Borgdorff, MW., Kremer, K., van Soolingen, D. Mycobacterium tuberculosis Beijing Genotype and Risk for Treatment Failure and Relapse, Vietnam. Emerging Infectious Diseases;2003:9(12): 1633-35

29. Hasan, Z., Tanveer, M., Kanji, A., Hasan, Q., Ghebremichael, S., Hasan, R., Spoligotyping of Mycobacterium tuberculosis Isolates from Pakistan Strain 1 and Beijing Isolates Reveals Predominance of Central Asian, J. Clin. Microbiol. 2006, 44(5):1763-1768

30. Van Crevel, Nelwan,R. H., de Lenne, W., Veeraragu,Y,.van der Zanden,A. G., Amin,Z.,. Mycobacterium tuberculosis Beijing genotype strains associated with febrile response to treatment.Emerg Infect Dis. SepOct;2001: 7(5): 880-883. 